\title{
Risks to children and young people during covid-19 pandemic
}

\author{
A shift in focus is needed to avoid an irreversible scarring of a generation
}

\author{
Peter Green chair \\ National Network of Designated Healthcare Professionals for Children, Children's Department, St George's University Hospital, London, UK
}

\begin{abstract}
Measures being taken to control the spread of covid-19 are causing what has been dubbed a "secondary pandemic" of child neglect and abuse. As one senior paediatrician summed it up: "Children are perversely suffering for the benefit of adults." The need to reduce the clinical effect on adults is urgent. However, in a very British fashion, ${ }^{3}$ the secondary harm being done to the adults of the future, when there is already an established child health crisis in the UK, ${ }^{4}$ is not being properly considered. This must change.
\end{abstract}

\section{Safeguarding risks}

Since the start of the epidemic the normal finger pointing of daily public discourse has been replaced by talk of collaboration, the importance of humanity, and saving lives. But this enlightened attitude lasts only up to a point. Behind the public discussion lies an altogether different conversation. Lockdown is the key word in this conversation, but subjecting vulnerable children to nothing other than family contact for an extended period sets up perfect conditions for a safeguarding failure.

Firstly, there is an increased opportunity for harm to befall children. The pressure cooker of family life is a standing joke, but it hangs on the truth that for some families staying at home together increases the chances of child abuse and neglect. Then there is the absence of any outside oversight. Without regular access to professionals such as teachers, general practitioners, health visitors, and social and youth workers, routine opportunities to spot signs or narratives of safeguarding concern are lost. Some social work staff have had to self-isolate, stretching safeguarding teams and straining service delivery.

At the same time, the message to stay at home and fears of infection have led to a nationwide decline in attendance at emergency departments $(25 \%)^{5}$ and general practice and a consequent reduction of face-to-face consultations. Lastly, a $22 \%$ increase in supermarket alcohol sales in March, ${ }^{6}$ which can only be for domestic consumption at this time, underscores the risk to children that the current regime represents.

Evidence that these concerns are not misplaced includes increased calls to child support lines ${ }^{7}$ and increased police attendance at domestic abuse incidents. Although imperfect, these signals suggest that child safeguarding activity can be expected to increase once the lockdown is removed and imply a workload that must be planned for and funded. As well as catching up on incomplete safeguarding business at the start of isolation, support staff will face added work arising from increased domestic risks. And to avoid an irreversible scarring of a generation, this work must be aligned with an ambitious plan to turn the corner of childhood outcomes for obesity, mental health, and premature and preventable deaths.

This will come about only with a wholesale change in our national approach to children. And it must start at the top. Only when governmental voices speak regularly about their concerns and plans for child welfare, with the same passion and at the same time that they speak of their efforts to save adult lives, will those who are constrained by the current silence feel empowered to develop the strategies and make the investment that can change the course of childhood wellbeing in the UK for good.

\section{Double assault}

Children and young people must be engaged with, spoken to, and guided into the future. Current declarations may be necessary to save adult lives, but they fail to explain anything in terms that children can understand and show no regard for what they need. It is not unreasonable to suggest that, for the 1 million to 2.3 million vulnerable children in the $\mathrm{UK},{ }^{8}$ many weeks of isolation in homes-without any preparatory talk about how their needs, whatever their infirmity or constraints, will be met-will only lead to confusion, lack of confidence, and increased anxiety. Breaking the mould of indifference is possible, as has been shown in talks by the prime ministers of Canada and New Zealand. ${ }^{910}$

Now that we have passed the peak of the pandemic, the talk in the UK must shift to children. We need to use the continuing deterioration of child health and the harm that this episode is doing to reform our behaviour. The government should come out of this episode striving to save its reputation as an agency fixed on adult success and biased against children. The actions 
to deal with this doubling of the assault on child wellbeing must start now.

Competing interests: We have read and understood BMJ policy on declaration of interests and have no relevant interests to declare.

Provenance and peer review: Not commissioned; not externally peer reviewed.

Adams C. Is a secondary pandemic on its way? Institute of Health Visiting, London, 6 April 2020. https://ihv.org.uk/news-and-views/voices/is-a-secondary-pandemic-on-its-way/ 2 Elliman D. Daily Covid 19 telephone conference of National Network of Designated Healthcare Professionals for Children, 15 April 2020.

3 Aynsley-Green A. The British betrayal of children. Routledge, 2019.

4 Horton R. Offline: the UK's child health emergency. Lancet 2018;392:106. 10.1016/S0140-6736(18)31614-3 30017117
5 Thornton J. Covid-19: A\&E visits in England fall by 25\% in week after lockdown. BMJ 2020;369:m1401. 10.1136/bmi.m1401 32253175

6 Ellson A. Coronavirus: bingeing Britons buy 20\% more alcohol for lockdown. Times 2020 Mar 31. https://www.thetimes.co.uk/article/coronavirus-bingeing-britons-buy-20-per-centmore-alcohol-for-lockdown-njh6jn55q

7 Hennessy M. "Isolated at home with their tormentor": Childline experiences increase in calls since closure of schools. The Journal $2020 \mathrm{Mar} 20$. https://www.thejournal.ie/childlinecalls-coronavirus-5053104-Mar2020/

8 Children's Commissioner. Childhood vulnerability in England2019. https://www. childrenscommissioner.gov.uk/publication/childhood-vulnerability-in-england-2019/

9 Prime minister appeals to Canadian children to follow social distancing rules. CBC News 2020 Mar 22. https://www.cbc.ca/news/politics/justin-trudeau-tells-kids-to-follow-socialdistancing-rules-1.5506113

10 New Zealand prime minister Jacinda Ardern confirms Easter Bunny. You Tube 7 Mar 2020. https://www.youtube.com/watch?v=C64c-PZ9-CE

Published by the BMJ Publishing Group Limited. For permission to use (where not already granted under a licence) please go to http://group.bmj.com/group/rights-licensing/ permissions 